\title{
Shoreline Change and its Impact on Land use Pattern and Vice Versa - A Critical Analysis in and Around Digha Area between 2000 and 2018 using Geospatial Techniques
}

\author{
Anindita Nath ${ }^{1 *}$, Bappaditya Koley ${ }^{2}$, Subhajit Saraswati ${ }^{1}$, Basudeb Bhatta ${ }^{3}$ and \\ Bidhan Chandra Ray ${ }^{4}$ \\ ${ }^{1}$ Departments of Construction Engineering, Jadavpur University, Kolkata, West Bengal, 700106 India \\ ${ }^{2}$ School of Oceanographic Studies, Jadavpur University, Kolkata, West Bengal, 700032 India \\ ${ }^{3}$ Computer Aided Design Centre, Jadavpur University, Kolkata, West Bengal, 700032 India \\ ${ }^{4}$ Department of Chemistry, Jadavpur University, Kolkata, West Bengal, 700032 India
}

\begin{abstract}
The shoreline is a very unpredictable, uncertain, and forever changing landscape for any coastal process. Due to erosional and accretional activities, the shoreline has continuously fluctuated with the continual process of waves and tides. Shore boundaries are determined by the shoreline at its furthest towards the sea (low tide) and extreme towards land (high tide). The present research aimed to identify the temporal alterations of shoreline and changes in land-cover between the areas of Rasulpur to Subarnarekha estuary, east coast of India with $70.04 \mathrm{~km}$ length of shoreline. An area amounting to $143 \mathrm{sq} . \mathrm{km}$ had been selected for showing the land-cover changing and this area had witnessed the rapid growth of population and increasing industrial activities causing an unsurpassable impact on the environment. The present study used three multi dated imageries for land use/ land cover (LULC) map and seven multi-resolution satellite images were applied to estimate the long-term shoreline change rate by dividing the coastal area into three "littoral zones" (LZ). The Digital shoreline analysis system

ARTICLE INFO

Article history:

Received: 07 July 2020

Accepted: 28 September 2020

Published: 22 January 2021

DOI: https://doi.org/10.47836/pjst.29.1.19

$\overline{\text { E-mail addresses: }}$

aninditan286@gmail.com (Anindita Nath)

bappadityakoley2012@gmail.com (Bappaditya Koley)

subhajitsaraswati@gmail.com (Subhajit Saraswati)

basubhatta@gmail.com (Basudeb Bhatta)

drbidhanray@gmail.com (Bidhan Chandra Ray)

* Corresponding author

(DSAS) was applied to identify the shoreline change rate of the year 2000 to 2018. Several statistical methods, linear regression rate (LRR), net shoreline movement (NSM), End Point Rate (EPR) were used to find out the erosion and accretion rate. The result showed that maximum erosion had been found in LZ III, rate of $-2.22 \mathrm{~m} /$ year. Maximum accretion had been identified in
\end{abstract}


LZ I, at the rate of $35.5 \mathrm{~m} /$ year. The LULC showed that maximum vegetation area had been decreased in the year of 2010 (14.21sq. km) but 38.96 sq.km vegetation area had increased in 2018. The prominent increase had been identified in built up and shallow water. Built up had been expanded from 25.59sq.km (2000) to 41.26sq.km (2018). Shallow water was increased from 5.53sq.km (2000) to 18.90sq.km (2018). Sand and soil showed a decreasing pattern from $2000-2018$. The outcome acquired from the present study will play a significant role to estimate the shoreline migration rate and will be helpful for sustainable land use management. The shoreline change rate will be also useful for coastal planners to adopt mitigation measures.

Keywords: Digital shoreline analysis system, end point rate, land use/land cover, littoral zone, linear regression rate, net shoreline movement

\section{INTRODUCTION}

Shoreline is relatively narrow strip of land adjacent to water bodies like sea or lake. Components of shoreline is controlled by the wave dynamics and sediment characteristics, slope, climate, vegetation, tide fluctuation and overall a littoral behavior. Equilibrium shoreline changes its configuration over a time period due to changing behavior of the agent (Pandian et al., 2004). Removal of sediment by erosional process is more vulnerable than accretion and widening of shoreline. Analysis of shoreline change leads to understanding coastal processes operating in a particular area in terms of frequency and magnitude. Anthropogenic factors also influence coastal morphology. Every coastal zone has its specific natural properties like, coastal slope, bathymetry and water density. Shoreline changes are the effects of some coastal processes like, breaking zone, breaker types of wave, breaking energy and so on. The surf zone where wave losses its energy and breaks are called the breaking wave zone. Braking type means the level of unstable movement within the wave (Koloa \& Samanta, 2013).

Coastal zones require a huge amount of spatial research to assess and predict the geomorphic changes (Murali \& Kumar, 2015). The land use/land cover (LULC) of an area that is a combined output of physical and manmade variable and processes. The present study fulfill the two main objectives, (i) to observe the shoreline changes and calculate the shoreline change rate along the area of Rasulpur river estuary to Subarnarekha river estuary in eastern coast of India, (ii) to identify and quantify the land-cover classes for the bench mark years 2000, 2010 and 2018 by using different GIS tools. The present study area has been subjected to many geo-environmental factors like beach sand loss, lack of sediment transport, shoreline retreat or transgression (erosion), destruction of mangroves, rapid growth of urbanization near shore areas, decreasing soil area and increase of water level which is become significant cause of concern. Identification and estimation of shoreline shifting is an important phenomenon for coastal management and coastal environment 
monitoring (Van \& Bihn, 2008). The output of the present study is the shoreline change and LULC maps that can be useful for coastal authority for coastal zone management plan for the study area.

Various studies can be found in the existing literature for the study of shoreline change and land use/land cover change using geospatial analysis. Present work is based on the scientific approach and methodology of several research details given in Table 1 .

Table 1

Scientific approach and methodology of several research details

\begin{tabular}{|c|c|}
\hline Scientific approach and methodology & Research \\
\hline $\begin{array}{l}\text { Geospatial analysis of shoreline and LULC changes through remote sensing } \\
\text { and GIS techniques. }\end{array}$ & Samanta \& Paul, 2016 \\
\hline Shoreline identification using satellite images & Garcia-Rubio et al., 2009 \\
\hline $\begin{array}{l}\text { Study of the land use and land cover changes and CRZ in the coastal area of } \\
\text { Ganjam district, Odisha. }\end{array}$ & Guru et al., 2014 \\
\hline $\begin{array}{l}\text { Assessment of shoreline changes along Nagapattinam coast using geospatial } \\
\text { techniques. }\end{array}$ & Mageswaran et al., 2015 \\
\hline $\begin{array}{l}\text { Sea level rise and shoreline changes: a geo-informatics appraisal of } \\
\text { Chandipur coast, Orissa. }\end{array}$ & Mukhopadhyay et al., 2011 \\
\hline Long and short-term shoreline changes along mangalore coast, India. & Kumar \& Jayappa, 2009 \\
\hline $\begin{array}{l}\text { Analysis of land use /land cover using remote sensing techniques -A case } \\
\text { study of Karur district, Tamil Nadu, India. }\end{array}$ & Balachandar et al., 2011 \\
\hline $\begin{array}{l}\text { Automatic shoreline detection and future prediction: a case study on Puri } \\
\text { Coast, Bay of Bengal, India. }\end{array}$ & Mukhopadhyay et al., 2012 \\
\hline Coastline change detection using remote sensing. & Alesheikh et al., 2007 \\
\hline
\end{tabular}

\section{STUDY AREA}

The length of $70.04 \mathrm{~km}$ shoreline in east coast of India, area between Rasulpur to Subarnarekha estuary part of West Bengal and Orissa respectively was selected for the present study (Figure 1). East coast of India along with Bay of Bengal is more inundation prone and various shocked related to ocean than west coast of India (Chatterjee, 1995). The study area is located between latitudes of $21^{\circ} 34^{\prime} 25^{\prime \prime} \mathrm{N}$ to $21^{\circ} 47^{\prime} 16^{\prime \prime} \mathrm{N}$ and longitudes $87^{\circ} 22^{\prime} 36^{\prime \prime}$ E to $87^{\circ} 52^{\prime} 55^{\prime \prime}$ E. Elevation of is less than $3 \mathrm{~m}$ in average above sea level (Umitsu \& Sen, 1987; Goodbred \& Kuehl, 2000; Khan \& Islam, 2008). Beach sand in the study area has been observed as similar to Subarnarekha sand which is mainly quartz and yellowish in color tone. The general conception is contracted that the beach sand has been supplied from Subarnarekha River not from Ganga (River Research Institute, 2009). The entire coastal zone is predominated by south west monsoon with subtropical humid climate and three several climate pattern identified these are (i) per-monsoon (March June), (ii) monsoon (June - October) and (iii) retreat monsoon (November - February) (Dey et al., 2005). Five important estuary areas have been observed in the study zone. 


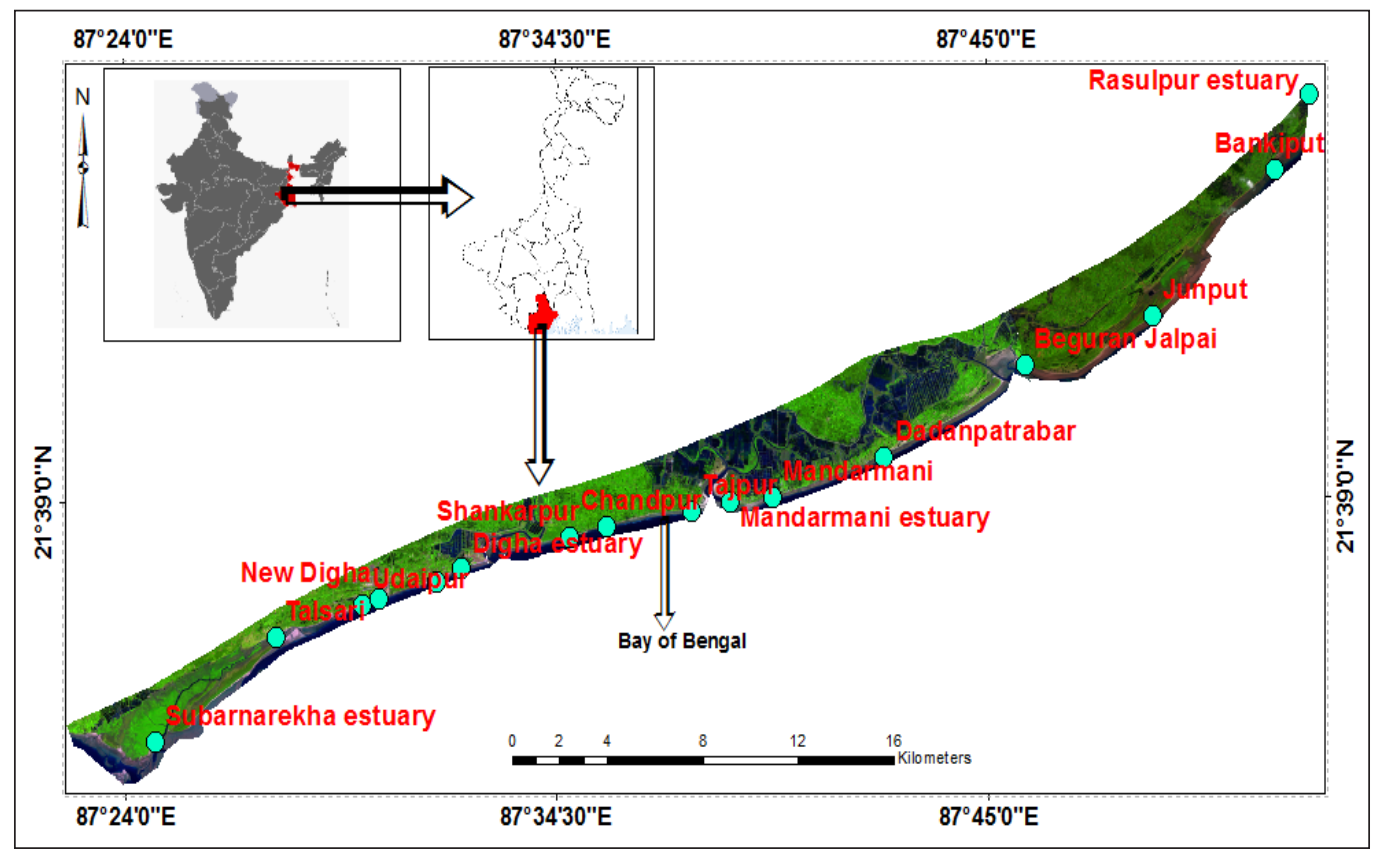

Figure 1. Geographical setting of study area

These are: Subarnarekha estuary (Subarnarekha River), Digha estuary (Digha canal and Champa River), Mandarmani estuary (Balisai canal and Sapua canal), BeguranJalpai (Pichabani canal and Contai canal) and Rasulpur estuary (Rasulpur River). The study area has witnessed rapid growth of urbanization due to development of tourism industry and various commercial activities are found in hinterland of the study area.

\section{METHODS}

Various methods of shoreline identification and shoreline retreat measures are available in the existing literature (Jana et al., 2013; Kuleli, 2009; Nguyen et al., 2010; Mujabar \& Chandrasekar, 2011; Selvan et al., 2014). The shoreline change detection is primarily based on the actual positioning of tidal datum that is mainly termed as mean high water (MHW) on a map (Everts et al., 1983). In this study, various remote sensing, and GIS methods (explained later) were applied to determine the shoreline position; land use/land cover changes. Different statistical analyses were also performed for estimating the shoreline retreatment rate. The following subsections explain different modules of methodology.

\section{Data Analysis}

The study was carried out using three multi-temporal and multi resolution images of Landsat $\mathrm{ETM}^{+}$(Enhanced thematic Mapper) with a spatial resolution of 30m for bands 1 to 7 and band 8 for $15 \mathrm{~m}$ and Landsat 8 (Operational Land Imager / OLI) and thermal 
infrared sensor (TIR) with a spatial resolution of $30 \mathrm{~m}$ for band 1 to 7 and 9, $15 \mathrm{~m}$ for band 8 , band 10 and 11 are thermal bands with a spatial resolution of $100 \mathrm{~m}$. In Landsat 8, band 1 is useful for coastal studies.

Available data over the selected period $(2000$ - 2018) had differences in their resolutions. Since the images were visually interpreted for mapping purpose, these differences of resolution did influence the accuracy to obtaining the real information about land cover features. Satellite image of 2000 is low resolution image with some atmospheric errors which create some problem in identifying the LULC features. The effect of low resolution has been observed especially in built up area of 2000 image. Landsat data are very much reliable in coastal studies and being used for decades (Munday \& Alfodi, 1979; Chand \& Acharya, 2010). Use of satellite images also proved its reliability in identifying the shoreline position and coastal changes (Boak \& Turner, 2005). The selected satellite images, for the years 2000, 2006, 2007, 2009, 2010, 2015 and 2018 were downloaded from USGS Global visualization viewer (https://glovis.usgs.gov).

\section{Identification and Estimation of Shoreline Change}

The shoreline was identified by interpreting the differences in shades of tone between the land and ocean. Brightness, contrast adjustment and histogram stretch techniques were applied on the satellite images for better visual identification. The pixels which represent the shoreline were converted into a polyline vector format in ArcGIS environment. In image of 2000 , some errors were observed related to atmospheric disturbances which generate some problem in extracting shoreline; and therefore, correction method was applied for this particular image. The least brightness value in every band was detected and this value was deducted from all pixel values (DN values) in the corresponding band that comport to atmospherically rectified image (Chavez, 1988; Trinh et al., 2020; Emran et al., 2016).

Prerequisite for change detection analysis are precise geometric correction (Saha et al., 2005). All of the satellite images were rectified geometrically in GIS application. Geometrically corrected images were projected by Universal Transverse Mercator (UTM) projection (WGS 84, Zone: 45N) based on nearest-neighbor interpolation technique. Then, standard false color composites (infrared color composites) were created for the satellite images.

To estimate the shoreline shifting rate, the Digital Shoreline Analysis System (DSAS) was most useful system available at USGS earth explorer website that performed with Arc GIS software in collaboration where shoreline change rate had been calculated following the "linear regression" (LR) method (Maiti \& Bhattacharya, 2009). The vector layers (.shp) of shoreline for the years $2000-2018$ were used in DSAS to estimate the rate of shoreline shifting. Transect information were required to estimating the change rate of shoreline and 2682 transects (in the form of shape file) were placed at $50 \mathrm{~m}$ interval along 
the shoreline. The DSAS tool was used to estimate the NSM (Net shoreline movement), EPR (End point rate) and LRR (Linear Regression Rate). The distance between youngest and oldest shorelines was demarcating the estimation of NSM. The LRR was demarcated by compatible least squares regression line to all the relative shoreline points of various years for a single transect. The EPR was estimated from the horizontal change rate of shorelines. The EPR was calculated by dividing the distance of horizontal shoreline change rate by the NSM (Thieler et al., 2009). The negative (-) values indicate the retreat of shoreline and positive $(+)$ values indicate the advance of shoreline or sea ward movement of shoreline. The total area (Subarnarekha estuary to Rasulpur river estuary) was divided into 3 littoral zones (LZ) for prominent identification of erosion and accretion pattern. The littoral zone is very close area to shoreline. This zone is influenced by the process of transportation and sedimentation. The total area was divided into different littoral segment based on important estuaries in the study area that were the main source of sediment supply over the area. First zone was selected Subarnarekha estuary to Digha estuary area (length of $23.04 \mathrm{~km}$ ) and 932 transects were drawn in this LZ I. Second zone was chosen from Digha estuary to BeguranJalpai (length of $31.15 \mathrm{~km}$ ) and 1051 number of transect were drawn to calculate the Shoreline change rate. Final zone was BeguranJalpai to Rasulpur river estuary area (length of $16.23 \mathrm{~km}$ ) with 699 number of transects. Three littoral zones were calculated by statistical method and finally a zonation map was prepared with five different zones according to LRR values and classes were defined based on their values in three littoral zones. Two specific classes were obtained: low erosion zone (range -100 to 0 ) and low accretion (range varies from 0 to 100). The entire study area has been observed by these two classes. The study shows the changes between 2000 - 2018 time periods (18 years) in a long-term method. The analysis was performed based on LRR and EPR method to showing the variation of shoreline change rate. LRR method was more compatible to showing the long-term changes than EPR method because in EPR method could not access more than two shorelines so when additional shorelines were assigned to calculate the change rate extra (more than two) shorelines were neglected. Due to this reason rate of shoreline migration might be overlooked. In case of LRR method, all shoreline data (more than two) were computed in regardless and the accurate rate of shoreline shifting was obtained using acceptable statistical techniques (Dolan et al., 2007). The present study had been applied both methods (EPR and LRR) to calculate the shoreline change rate and variation in both methods.

To justify the location of shoreline a validation method was applied for 2000, 2006, 2007, 2009, 2010, 2015 and 2018 shoreline. These three shorelines were converted into Google earth $(. \mathrm{kml})$ version; and then by the using of Google earth historical imagery system these three shorelines were validated. 


\section{Study of Land Use/ Land Cover}

Satellite images and field data were used to classify land cover features (Pal et al., 2012). The image classification resulted in the classified land-cover maps for the years 2000 , 2010 and 2018. Image classification was performed in Arc GIS software for following land-cover classes: vegetation, soil, shallow water, sand and built-up. To preparing the LULC map approximate $143 \mathrm{sq} . \mathrm{km}$ area was chosen. The total area was divided into three littoral zones (LZ) for each year. The LULC classification was performed for these three zones of each year to make a comparative study between $2000-2018$ time periods. The maximum likelihood classification algorithm was used to create this land use/ land cover map. Maximum likelihood classification is a process where known classes are distributed as the maximum for a certain statistic (Scott \& Symons, 1971; Mukhopadhyay et al. 2013; Mukhopadhyay et al. 2018). The training samples or signatures were collected from the images by means of visual image interpretation with appropriate ground truthing. From the LULC data, some statistical techniques were adopted to find out the drastic changes between 2000 - 2018 timwere. No classified map has been considered as accurate without performing the accuracy assessment (Bradley, 2009). To assess any classified image, confusion matrix is the most suitable method (Story \& Congalton, 1986; Biging et al., 1998; Oumer, 2009; Zhang et al., 2000; Mujabar \& Chandrasekar, 2013). Based on this method, similar and dissimilar pixels are assembled to compare the ground truth pixel along the location in classified map. Ground truth data are represented through column and classified pixel data are represented by row (SCGE, 2011). The matrix was performed by calculating user's accuracy, producer's accuracy and overall accuracy measures based on the commission and omission error (Coppin \& Bauer, 1996; Boschetti et al., 2004; Carlotto, 2009). Finally, the accuracy assessment was performed to determinethe overall accuracy and Kappa co-efficient accuracy (Rossiter, 2014). The result of accuracy assessment is given in Table 2.

Overall accuracy as in Equation 1:

$$
\frac{\sum_{\mathrm{a}-1}^{\mathrm{U}} \mathrm{C}_{\mathrm{a}}}{\mathrm{Q}} * 100 \%
$$

Where, $\mathrm{Q}$ and $\mathrm{U}$ is the number of total pixel and classes, respectively. The acceptable overall accuracy has been considered 85\% (Congalton \& Green, 1999; Lu \& Weng, 2007; Li \& Zhou, 2009).

Kappa confusion matrix is demarcated as in Equation 2:

$$
\mathrm{K}=\frac{\sum_{\mathrm{a}-1}^{\mathrm{U}} \frac{\mathrm{C}_{\mathrm{a}}}{\mathrm{Q}} \sum_{\mathrm{a}-1}^{\mathrm{U}} \frac{\mathrm{C}_{\mathrm{aC}}}{\mathrm{Q}^{2}}}{1-\sum_{\mathrm{a}-1}^{\mathrm{U}} \frac{\mathrm{C}_{\mathrm{a} \cdot \mathrm{C}_{\mathrm{a}}}}{\mathrm{Q}^{2}}}
$$

Where, $\mathrm{C}_{\mathrm{a}}$. $=$ Row sum 
Table 2

Showing the accuracy assessment by Kappa Co-efficient

\begin{tabular}{ccccccc}
\hline \multirow{2}{*}{$\begin{array}{c}\text { LULC feature } \\
\text { name }\end{array}$} & \multicolumn{3}{c}{ Producer's accuracy } & \multicolumn{3}{c}{ User's accuracy } \\
\cline { 2 - 6 } & 2000 & 2010 & 2018 & 2000 & 2010 & 2018 \\
\hline Built up & $100 \%$ & $100 \%$ & $71.43 \%$ & $37.5 \%$ & $90 \%$ & $71.43 \%$ \\
Vegetation & $100 \%$ & $90 \%$ & $100 \%$ & $87.50 \%$ & $100 \%$ & $100 \%$ \\
Soil & $66.66 \%$ & $100 \%$ & $71.43 \%$ & $100 \%$ & $85.71 \%$ & $100 \%$ \\
Sand & $77.77 \%$ & $90 \%$ & $100 \%$ & $100 \%$ & $100 \%$ & $90 \%$ \\
Shallow water & $100 \%$ & $100 \%$ & $100 \%$ & $100 \%$ & $100 \%$ & $89 \%$ \\
\hline & Overall accuracy & & $85 \%$ & $95 \%$ & $90 \%$ \\
& Kappa co-efficient & & $81.25 \%$ & $93.67 \%$ & $87.43 \%$ \\
\hline
\end{tabular}

\section{RESULT AND DISCUSSION}

\section{Shoreline Change Analysis}

The shoreline change or shoreline recession had been estimated for the area under Subarnarekha to Rasulpur river estuary area using Digital Shoreline Analysis System (DSAS) tool in Arc GIS 10.3 software. In the study area, shoreline length of $70.04 \mathrm{~km}$ observed both erosion and accretion (Figure 2, 3, 4). The shorelines of different years were drawn in ArcGIS. From the DSAS analysis, EPR and LRR for every transect length over the shoreline is shown in Figure 5,6 and 7. From the DSAS transect analysis it was observed that in the LZ I (Figure 2) maximum area was under low erosion to low accretion regime. But near Subarnarekha estuary a prominent accretion zone was found but at the same area also experiences the erosional tendency (Figure 2). The average positive LRR value was found as $35.5 \mathrm{~m} /$ year near Subarnarekha estuary and average negative changes of LRR value was $-1.5 \mathrm{~m} /$ year was observed in the extent part of Subarnarekha estuary to before Talsari area and near Old Digha, New Digha and Digha estuary area which is under low accretion zone. A tetrapod groin was constructed near Digha estuary area for the purpose of sedimentation which protects the beach area from coastal erosion in the year of 2007 by fishery Dept, Govt. of West Bengal (Figure 8). While in the LZ II (Figure 3) it was noticed that maximum area was dominated by low accretional formation and some area near Tajpur and Mandarmani estuary was under low erosional regime. The erosion rate was varying between -0.64 to $-1.85 \mathrm{~m} /$ year and positive changes rate was $10.15 \mathrm{~m} /$ year in LRR value. In the LZ III reflects that the area had experienced low erosional pattern (Figure 4). Junput area was under accretion regime with average $32.33 \mathrm{~m} /$ year LRR value whereas Rasulpur river estuary was under low erosional regime with $-2.22 \mathrm{~m} /$ year LRR value. Bankiput area was under accretion zone but some part of Bankiput shoreline remarked as domination of erosion with rate of $-3.23 \mathrm{~m} /$ year. Figures 5, 6 and 7 explain the prominence of LRR method to estimating the long-term shoreline migration compare to EPR method in LZ I, II and III. In LRR statistics every change magnitude had been computed which was absence in EPR method and accurate change rate was obtained by LRR method. In case of LZ 


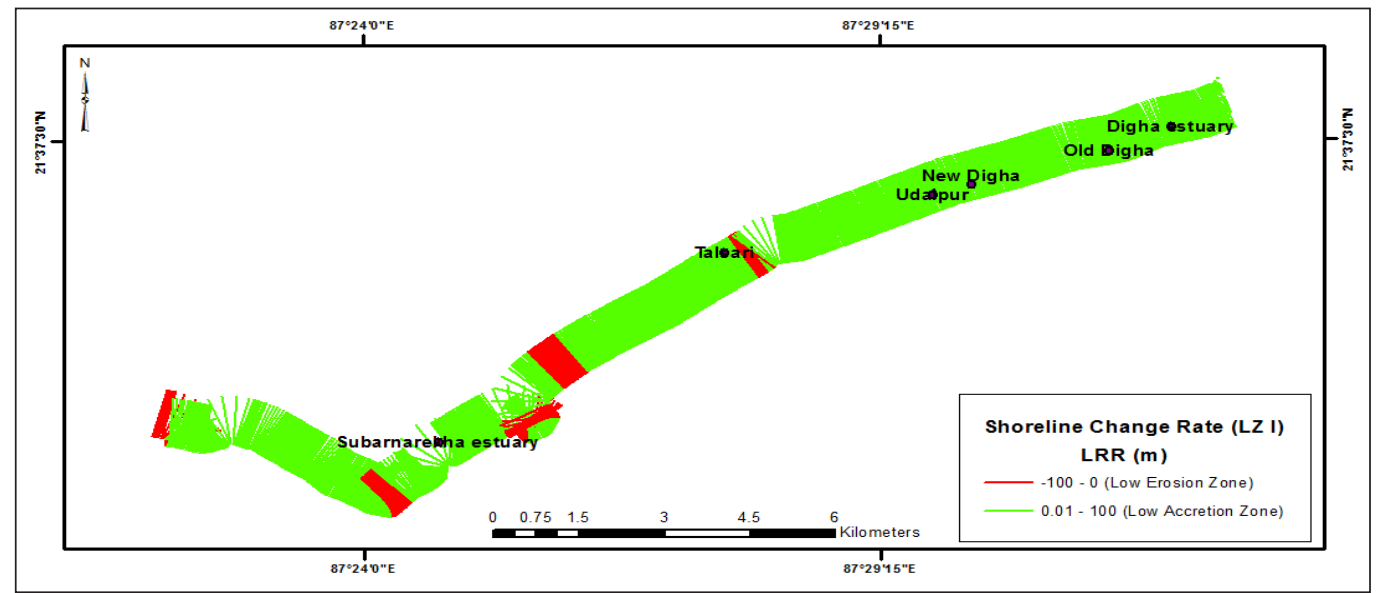

Figure 2. Shoreline change dynamics of LZ 1 (2000-2018)

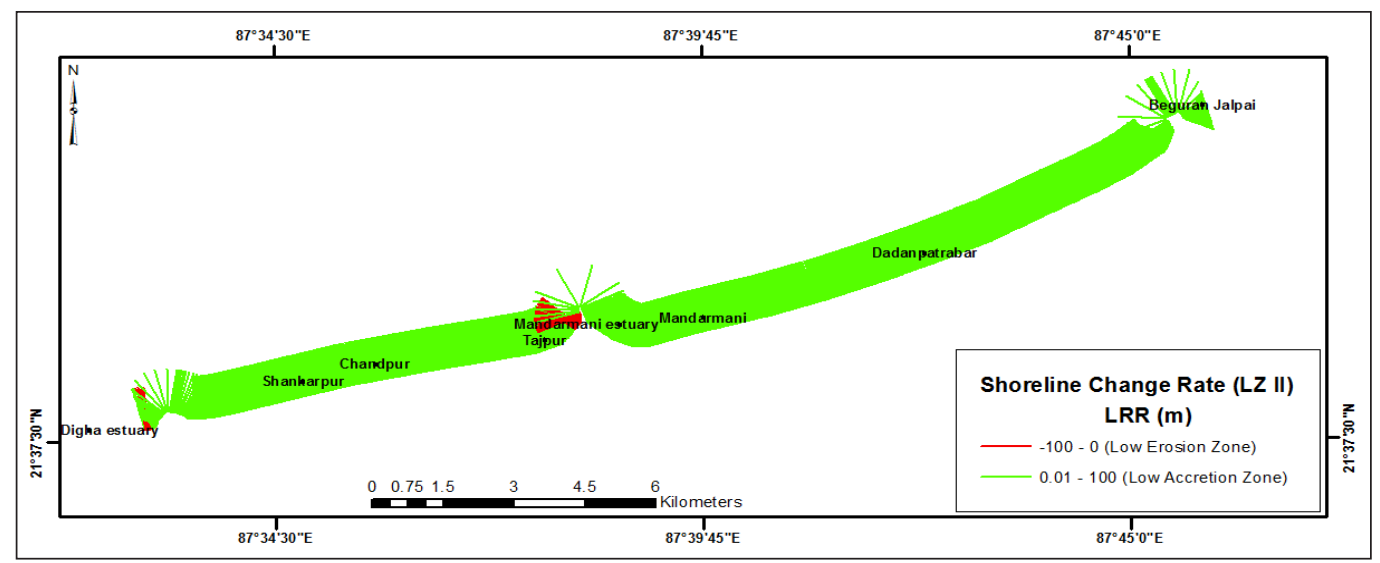

Figure 3. Shoreline change dynamics of LZ 2 (2000-2018)

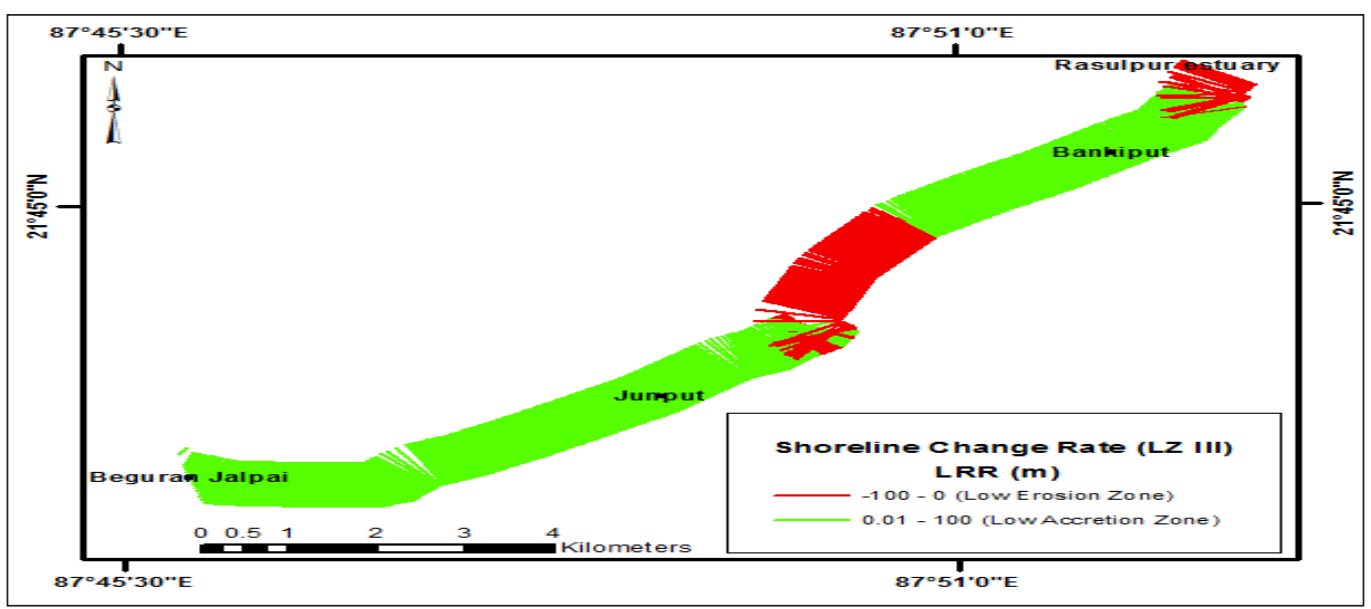

Figure 4. Shoreline change dynamics of LZ 3 (2000-2018) 
Anindita Nath, Bappaditya Koley, Subhajit Saraswati, Basudeb Bhatta and Bidhan Chandra Ray

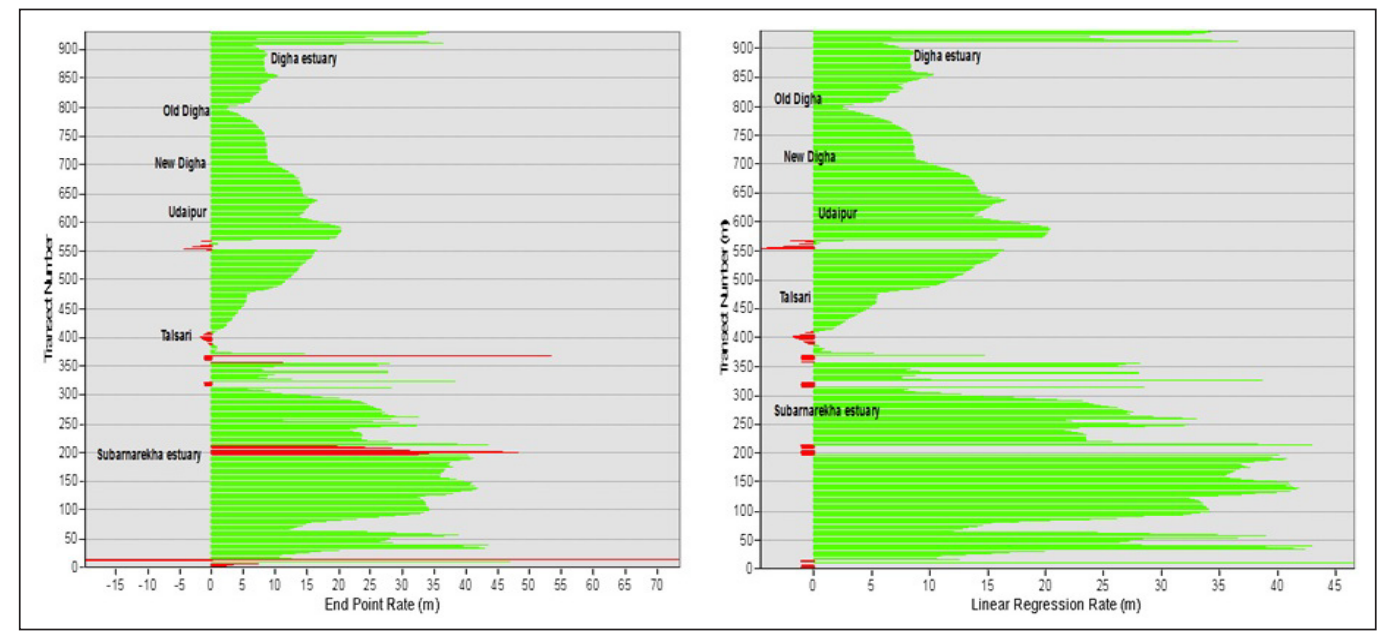

Figure 5. Graphical representation of shoreline changes in LZ I by EPR \& LRR (2000 - 18)
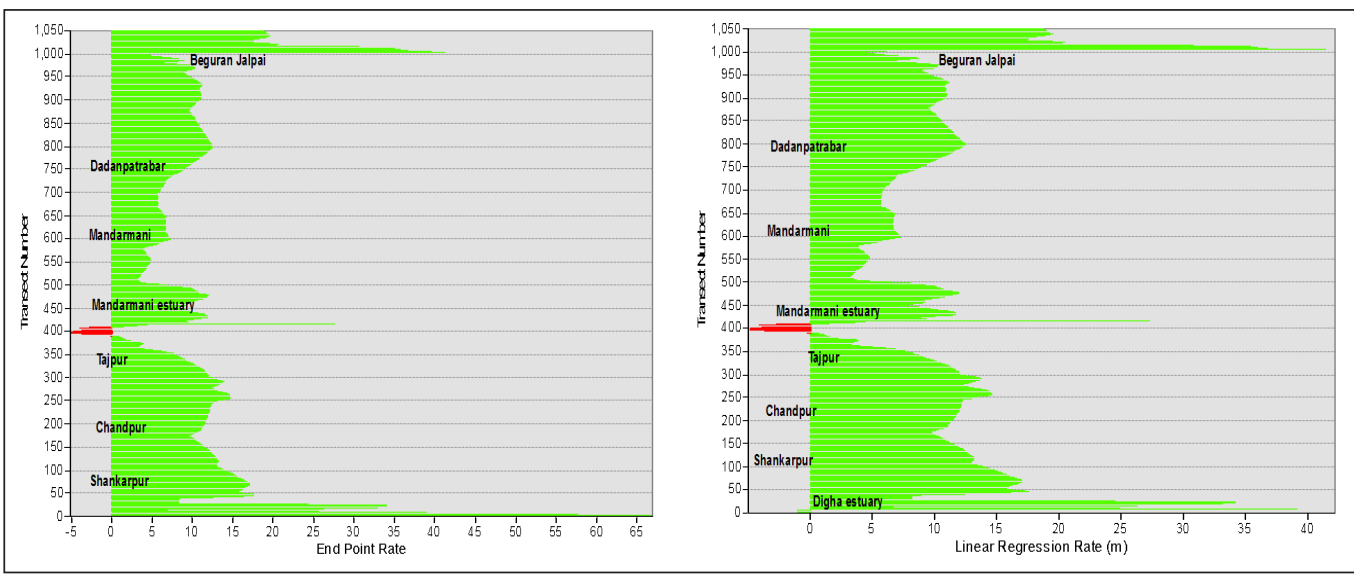

Figure 6. Graphical representation of shoreline changes in LZ II by EPR \& LRR (2000 - 18)
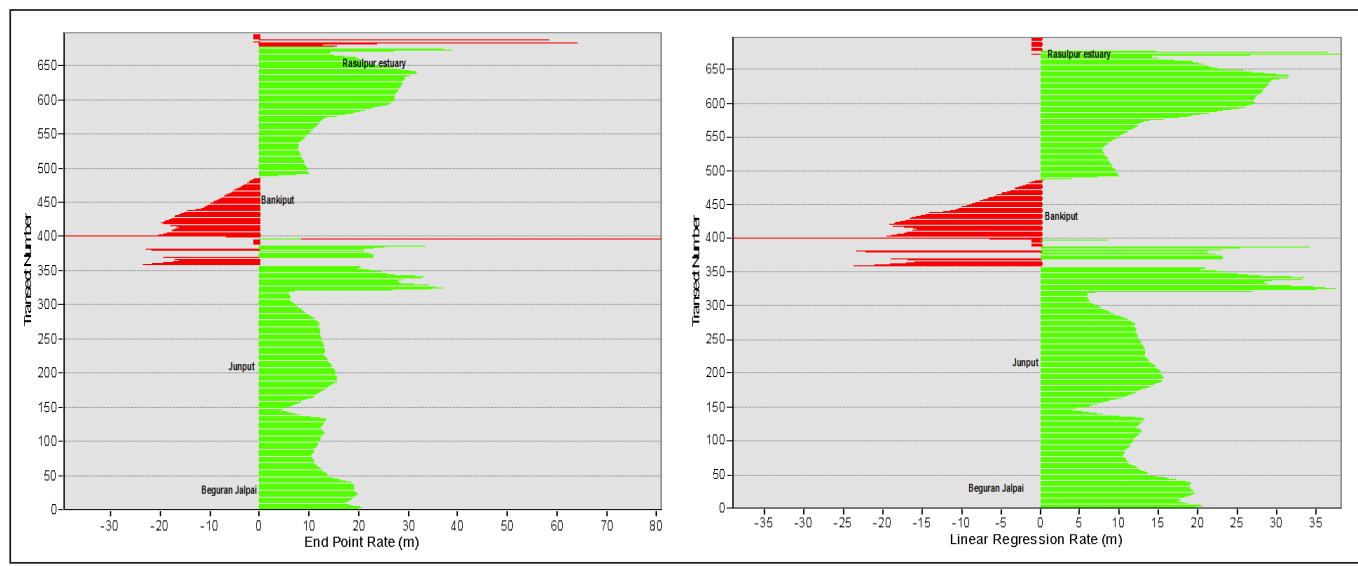

Figure 7. Graphical representation of shoreline changes in LZ III by EPR \& LRR (2000-18) 


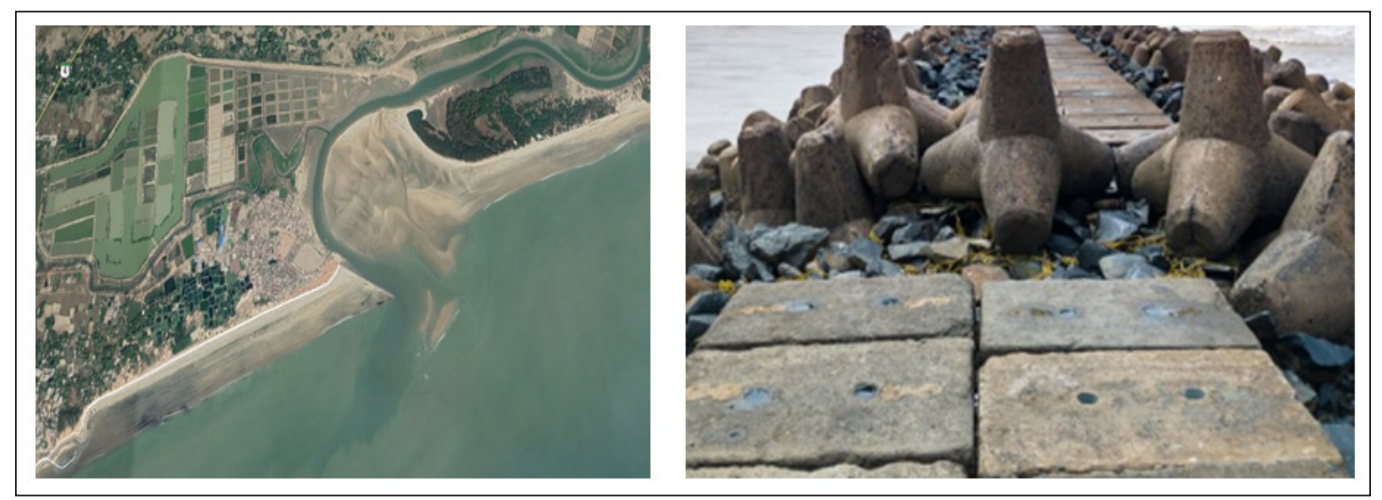

Figure 8. Google earth image of Digha estuary and tetrapod groin

III, the LRR graph showed the prominent erosion in Bankiput and Rasulpur estuary with signified value but in EPR method the values were distracted from erosion to accretion zone due to its adaptation problem in multiple shoreline data. LZ I also experienced the same in Subarnarekha estuary area (Figure 5). Due to this problem, to estimate the longterm shoreline change rate LRR was the most compatible method.

\section{Spatial Changes in Land Use/ Land Cover Mapping}

The land use/land cover classification was done for an area of approximate 143sq.km. From this LULC map it was observed that drastic changes occurred from 2000 to 2018 (Figures 9, 10, 11). To identify the prominent change, total area was divided into three littoral zones (LZ) as stated earlier. LZ I (Figure 9) of 2000, 2010, 2018 LULC maps showed that the maximum soil area could be found in the year 2000 but it was reduced rapidly from 2010 to 2018 . This zone also showed that how built-up area was enhanced within the time span 2000 to 2018 . However, the growth of vegetation was observed after 2010 and it was increased in 2018. It happened because plantation initiative was adopted to protect the shoreline from coastal erosion by West Bengal Govt. after 2010. In the year 2000, shallow water was observed in few areas but from 2010 the increasing trend of water level was found prominently. In LZ II (Figure 10) it was observed that built-up area was low in 2010 but in 2018 LULC map built-up increased again. In this zone, soil area was low in 2000 and 2018, but in the year 2010 maximum soil area was found. Shallow water area was increased from 2010. Maximum sand area was observed in the year 2000. Vegetation was increased after 2010. Most of the built-up area found in Mandarmani to Dadanpatrabar region. The LZ III (Figure 11) was most accreted area where high vegetation cover was found in 2000 and 2018 but in 2010 vegetation cover was reduced. Sand area of higher coverage was observed clearly in 2000 but from 2010 it was decreased. Built-up area was found mostly in 2010and 2018. This zone clearly showed that water level was high in 2010 and 2018 map. Maximum soil area was found in 2010. 
Anindita Nath, Bappaditya Koley, Subhajit Saraswati, Basudeb Bhatta and Bidhan Chandra Ray

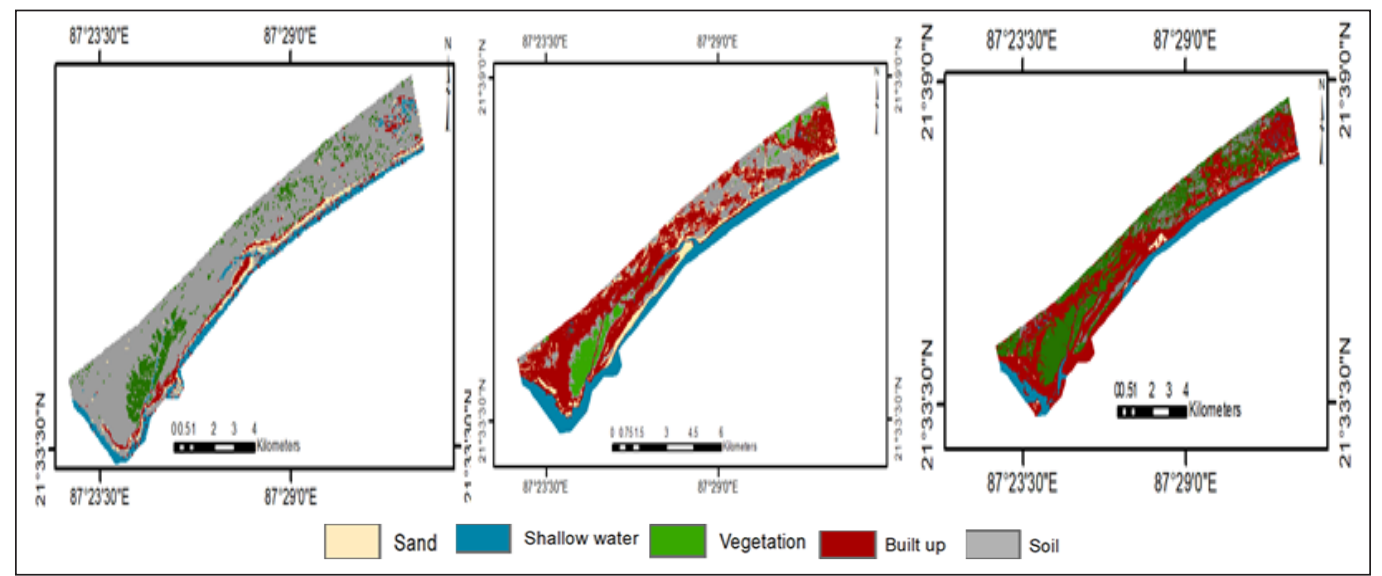

Figure 9. LULC map of LZ I in 2000, 2010, 2018

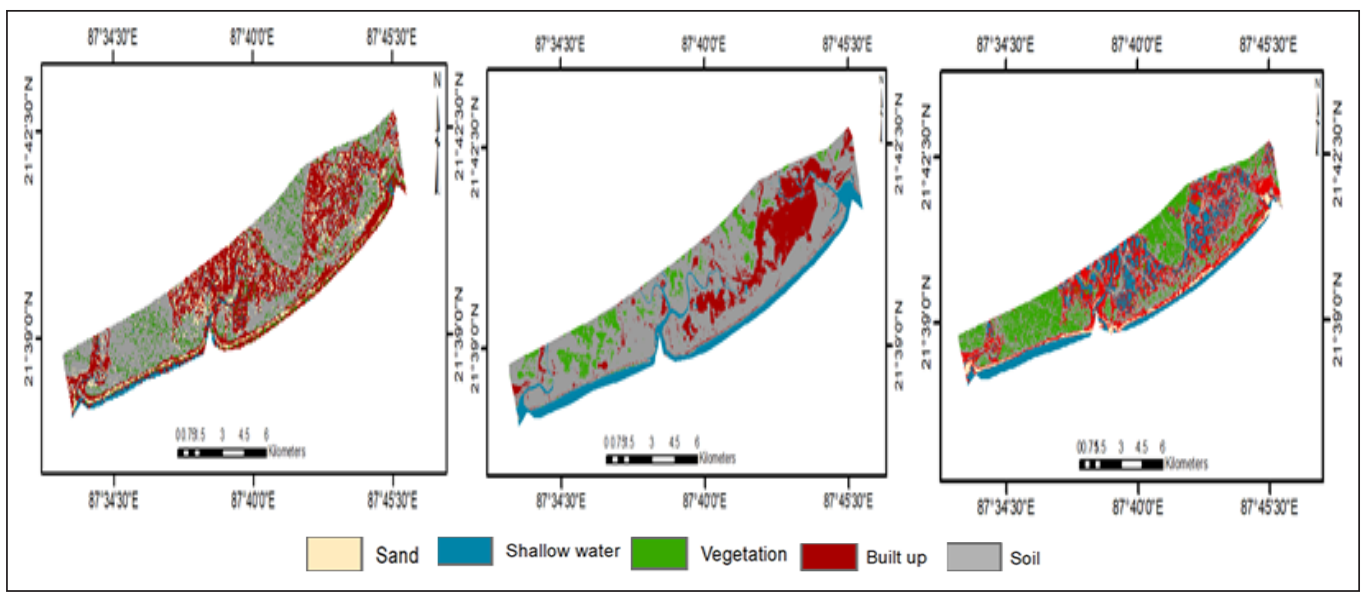

Figure 10. LULC map of LZ II in 2000, 2010, 2018

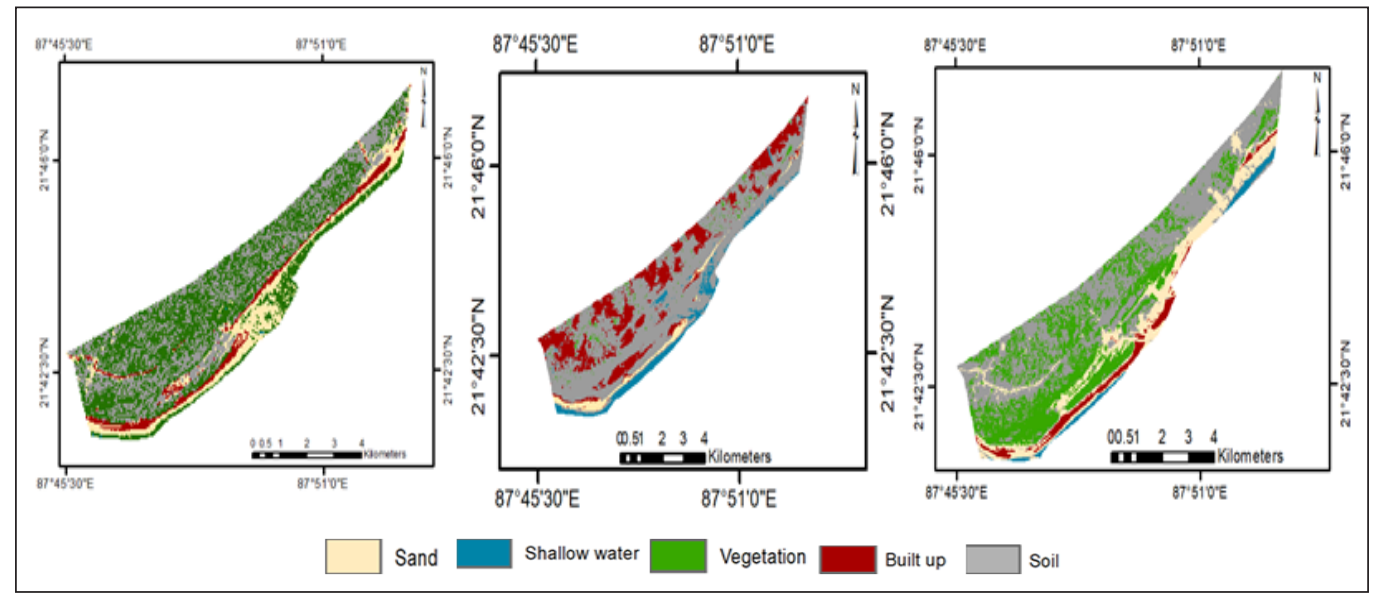

Figure 11. LULC map of LZ III in 2000, 2010, 2018 


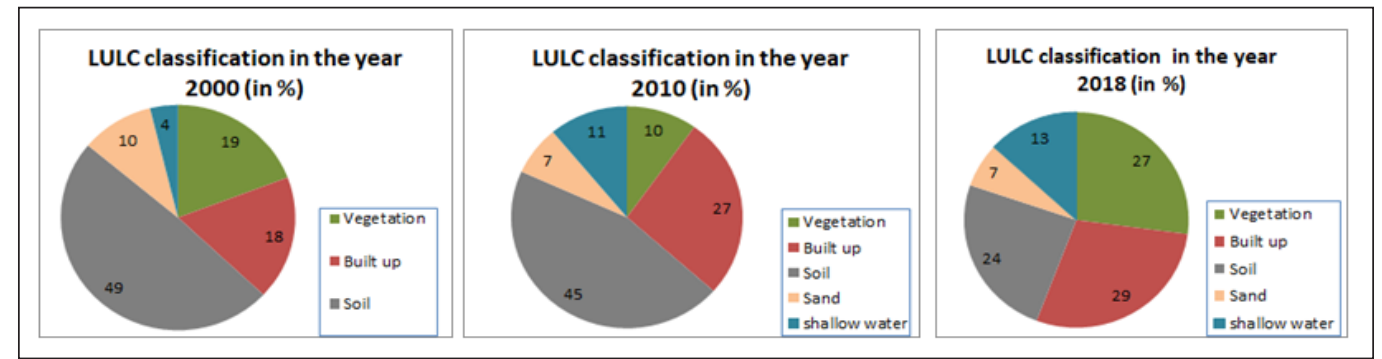

Figure 12. LULC area in percentage $(2000-2018)$

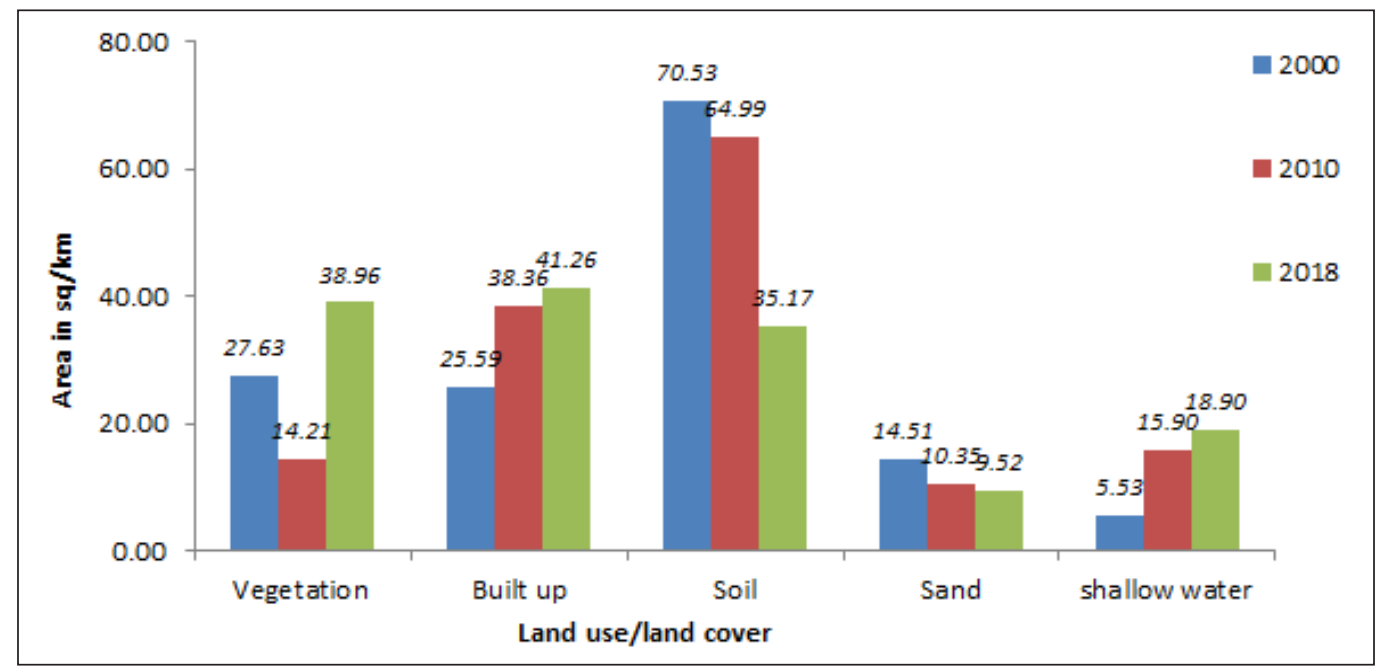

Figure 13. LULC area in sq.km (2000 - 2018)

Figure 12 shows the total changes in percentage. Figure 12 explains the drastic changes that occurred between $2000-2018$ time span. The built-up area increased in 2000-2018 from $18 \%$ to $29 \%$ where shallow water level also increased in these 18 years from $4 \%$ to $13 \%$. But soil area was reduced from $49 \%$ in 2000 to $45 \%$ in 2010 and $24 \%$ in 2018. Sand area was observed $10 \%$ in 2000 but decreased $7 \%$ in 2018 . Vegetation was $19 \%$ in 2000 but it decreased to $10 \%$ in 2010 . Sand area increased again in 2018 to $27 \%$.

Figure 13 shows the LULC area in sq.km from 2000 - 2018 in approx. 143sq.km. This distribution shows that vegetation area was increased from $27.63 \mathrm{sq} . \mathrm{km}$ to $38.96 \mathrm{sq} . \mathrm{km}$. Built-up area was enhanced from 25.69sq.km to $41.26 \mathrm{sq} . \mathrm{km}$. Maximum drastic changes were observed in soil area that was decreased rapidly from $70.59 \mathrm{sq} . \mathrm{km}$ to $35.17 \mathrm{sq} . \mathrm{km}$ in 18 years. Shallow water was also increased from 5.5 sq.km to $18.90 \mathrm{sq} . \mathrm{km}$ during the same time span.

From the accuracy assessment, it has been observed that maximum producer's accuracy was obtained in built up, vegetation and shallow water, whereas the maximum user's accuracy was obtained in class of soil, sand, and shallow water area $(2000,2010,2018)$. 
The overall accuracy of $85 \%$ and Kappa co-efficient $81.25 \%$ has been obtained from the assessment. The built-up area showed the lowest user's accuracy in 2000 map (37.5\%) due to the low resolution of the image. In the classified map of 2010, the highest producer's accuracy was found in built up, soil and shallow water area and accurate user's accuracy was reflects in vegetation, sand and shallow water area with $95 \%$ overall accuracy and 93.67\% Kappa co-efficient. The classified image of 2018 remarked the highest producer's accuracy in vegetation, sand and shallow water area and highest user's accuracy reached in vegetation and soil area where the overall accuracy was $90 \%$ and Kappa co-efficient accuracy was $87.43 \%$ (Table 2 ).

\section{CONCLUSION}

The use of remote sensing data to find out the erosion - accretion patterns and LULC changes has been presented in this work. The research presented multi-temporal LULC status of the study area with coverage of $143 \mathrm{sq} . \mathrm{km}$ and it also presented shoreline shifting analysis for a length of $70.04 \mathrm{~km}$. Over the last 18 years the entire area has been facing shoreline advance and retreat related problems, resulting in destructions to the environmental situation of the coastal area. The entire area under observation had been broadly divided into three "littoral zones" (LZ I to LZ III). The LZ I zone shows an average negative LRR value of $-0.45 \mathrm{~m} /$ year and positive change rate value of $15.5 \mathrm{~m} /$ year. The $\mathrm{LZ}$ I also showed erosion of $-1 \mathrm{~m} /$ year LRR and $10.15 \mathrm{~m} /$ year positive LRR change values. The LZ III was under accretion and erosional situation. The erosion change rate was found an average of $-2.22 \mathrm{~m} /$ year and accretion change rate was $32 \mathrm{~m} /$ year LRR value. The LULC analysis showed that maximum built-up areas were concentrated in LZ 1 and built-up areashave been enhanced after the year 2000. Subarnarekha estuary to Digha estuary area observed immense pressure of urbanization from 2010. From these three LZ maps it could be observed prominently that shallow water was increased from 2010 to 2018. Finally, the present work shows the shoreline changes and prepares LULC maps that will play a very significant role for decision makers to identify and protect the susceptible zones and invent better mitigation methods for associated coastal problems.

\section{ACKNOWLEDGEMENT}

I would like to express my special thanks to Irrigation \& Waterways Department and River Research Institute, West Bengal, India for their cooperation in date collection and field survey. I am thankful to Mr. Amiya Bera, Deputy Director (Structure), Irrigation \& Waterways Department, West Bengal, Kolkata and Dr. Bibhas Chandra Barman, Deputy Director, River Research Institute, Mohanpur, Nadia, West Bengal, India for their heartfelt contribution. I also thankful to Mr. Bimal Adak, field investigator at Digha, (RRI) West Bengal, India for his support during field visit. 


\section{REFERENCES}

Alesheikh, A. A., Ghorbanali, A., \& Nouri, N. (2007). Coastline change detection using remote sensing. International Journal of Environmental Science and Technology, 4(1), 61-66. doi: https://doi.org/10.1007/ BF03325962

Balachandar, D., Rutharvel M. K., Muruganandam, R., Sumathi, M., Sundararaj, P., \&Kumaraswamy, K. (2011). Analysis of land use/ land covers using remote sensing techniques-A case study of Karur district, Tamil Nadu, India. International Journal of Current Research, 3(12), 226-229.

Biging, G. S., Colby, D. R., \&Congalton, R. G. (1998). Sampling systems for change detection accuracy assessment, remote sensing change detection. In R. S. Lunetta \& C. D. Elvidge (Eds.), Environmental monitoring methods and applications (pp. 281-308). Michigan, USA: Ann Arbor Press.

Boak, E., \& Turner, I. (2005). Shoreline definition and detection: A review. Journal of Coastal Research, 21(4), 688-703. doi: https://doi.org/10.2112/03-0071.1

Boschetti, L., Flasse, S. P., \& Brivio, P. A. (2004). Analysis of the conflict between omission and commission in low spatial resolution dichotomic thematic products: The pareto boundary. Remote Sensing of Environment, 91(3-4), 280-292. doi: https://doi.org/10.1016/j.rse.2004.02.015

Bradley, B. A. (2009). Accuracy assessments of mixed land cover using a GIS-designed sampling scheme. International Journal of Remote Sensing, 30(13), 3515-3529. doi: https://doi. org/10.1080/01431160802562263

Carlotto, M. J. (2009). Effect of errors in ground truth on classification accuracy. International Journal of Remote Sensing, 30(18), 4831-4849. doi: https://doi.org/10.1080/01431160802672864

Chand, P., \& Acharya, P. (2010). Shoreline change and sea level rise along coast of Bhitarkanika wildlife sanctuary, Orissa: An analytical approach of remote sensing and statistical techniques. International Journal of Geomatics and Geosciences, 1(3), 436-455.

Chatterjee, R. K. (1995). A comparative study between East and West Indian Coast: A geographical account. Geographical Review of India, 12(1), 23-25.

Chavez, J. R. (1988). An improved dark-object subtraction technique for atmospheric scattering correction of multispectral data. Remote Sensing of Environment, 24(3), 459-479. doi: https://doi.org/10.1016/00344257(88)90019-3

Congalton, R. G., \& Green, K. (1999). Assessing the accuracy of remotely sensed data: Principles and practices. Boca Raton, Florida: CRC Press, Taylor \& Francis Group.

Coppin, P. R., \& Bauer, M. E. (1996). Digital change detection in forest ecosystems with remote sensing imagery. Remote Sensing Reviews, 13(3-4), 207-234. doi: https://doi.org/10.1080/02757259609532305

Dey, S., Ghosh, P., \& Nayak, A. (2005). The influences of natural environment upon the evolution of sand dunes in tropical environments along Medinipore coastal area, India. Indonesian Journal of Geography, $37(1), 51-68$.

Dolan, R., Fenster, M. S., \& Holme, S. J. (1991). Temporal analysis of shoreline recession and accretion. Journal of Coastal Research, 7(3), 723-744. 
Emran, A., Rob, M. A., Kabir, M. H., \& Islam, M. N. (2016). Modeling spatio-temporal shoreline and areal dynamics of coastal island using geospatial technique. Modeling Earth Systems and Environment, 2(4), 1-11. doi: 10.1007/s40808-015-0060-z.

Everts, C. H., Battley Jr, J. P., \& Gibson, P. N. (1983). Shoreline movements. Report 1. Cape Henry, Virginia, to Cape Hatteras, North Carolina, 1849-1980 (No. CERC-83-1-1). Technical Report. Coastal Engineering Research Center Vicksburg MS.

Garcia-Rubio, G., Huntley, D., Kingston, K., \& Esteves, L. S. (2009). Shoreline identification using satellite images. Coastal Dynamics, 2009, 1-10. doi: 10.1142/9789814282475_0117

Goodbred Jr, S. L., \& Kuehl, S. A. (2000). The significance of large sediment supply, active tectonism, andeustasy on margin sequence development: Late quaternary stratigraphy and evolution of the Ganges-Brahmaputra delta. Sedimentary Geology, 133(3-4), 227-248. doi: https://doi.org/10.1016/ S0037-0738(00)00041-5

Guru, B., Neha, M., \& Anubhooti, Y. (2014, December 9-12). Study the land use and land cover changes and CRZ in the coastal area of Ganjam District, Odisha. In International Society of Photogrammetry and Remote Sensing (ISPRS), Mid-Term Symposium of the Technical Commission VIII (pp. 1-5). Hyderabad, India.

Jana, A., Biswas, A., \& Maiti, S. (2013). Shoreline changes in response to sea level rise along Digha Coast, Eastern India: An analytical approach of remote sensing, GIS and statistical techniques. Journal of Coastal Conservation, 18(3), 145-155. doi: https://doi.org/10.1007/s11852-013-0297-5

Khan, S. R., \& Islam, B. (2008). Holocene stratigraphy of the lower Ganges-Brahmaputra river delta in Bangladesh. Frontiers of Earth Science in China, 2(4), 393-399. doi: https://doi.org/10.1007/s11707008-0051-8

Koloa, C., \& Samanta, S. (2013). Development impact assessment along Merkham River through remote sensing and GIS technology. International Journal Asian Academy Research Association, 5(1), 26-41.

Kuleli, T. (2009). Quantitative analysis of shoreline changes at the Mediterranean Coast in Turkey. Remote Sensing of Environment, 167(1-4), 387-397. doi: https://doi.org/10.1007/s10661-009-1057-8

Kumar, A., \& Jayappa, K. S. (2009). Long and short-term shoreline changes along Mangalore Coast, India. International Journal Environmental Research, 3(2), 177-188.

Li, B., \& Zhou, Q. (2009). Accuracy assessment on multi-temporal land-cover change detection using a trajectory error matrix. International Journal of Remote Sensing, 30(5), 1283-1296. doi: https://doi. org/10.1080/01431160802474022

Lu, D., \&Weng, Q. (2007). A survey of image classification methods and techniques for improving classification performance. International Journal of Remote Sensing, 28(5), 823-870. doi: https://doi. org/10.1080/01431160600746456

Mageswaran, T., Mohan, V. R., Selvan, S. C., Arumugam, T., Usha, T., \& Kankara, R. S. (2015). Assessment of shoreline changes along Nagapattinam coast using geospatial techniques. International Journal of Geomatics and Geosciences, 5(4), 555-563. 
Maiti, S., \& Bhattacharya, A. K. (2009). Shoreline change analysis and its application to prediction: A remote sensing and statistics based approach. Marine Geology, 257(1-4), 11-23. doi: https://doi.org/10.1016/j. margeo.2008.10.006

Mujabar, P. S., \& Chandrasekar, N. (2011). Coastal erosion hazard and vulnerability assessment for southern coastal Tamil Nadu of India by using remote sensing and GIS. Natural Hazards, 69(3), 1295-1314. doi: https://doi.org/10.1007/s11069-011-9962-x

Mujabar, P. S., \& Chandrasekar, N. (2013). Shoreline change analysis along the coast between Kanyakumari and Tuticorin of India using remote sensing and GIS. Arabian Journal of Geosciences, 6(3), 647-664. doi: https://doi.org/10.1007/s12517-011-0394-4

Mukhopadhyay, A., Hornby, D. D., Hutton, C. W., Lázár, A. N., Johnson, F. A., \& Ghosh, T. (2018). Land cover and land use analysis in coastal Bangladesh. In Ecosystem Services for Well-Being in Deltas (pp. 367-381). Cham, Switzerland: Palgrave Macmillan.

Mukhopadhyay, A., Mukherjee, S., Garg, R. D., \& Ghosh, T. (2013). Spatio-temporal analysis of land use - land cover changes in Delhi using remote sensing and GIS techniques. International Journal of Geomatics and Geosciences, 4(1), 212-223.

Mukhopadhyay, A., Mukherjee, S., Hazra, S., \& Mitra, D. (2011). Sea level rise and shoreline changes: A geo-informatics appraisal of Chandipur coast, Orissa. International Journal of Geology, Earth and Environmental Sciences, 1(1), 9-17.

Mukhopadhyay, A., Mukherjee, S., Mukherjee, S., Gosh, S., Hazra, S., \& Mitra, D. (2012). Automatic shoreline detection and future prediction: A case study on Puri Coast, Bay of Bengal, India. European Journal of Remote Sensing, 45(1), 201-213. doi: https://doi.org/10.5721/EuJRS20124519

Munday, J. C., \& Alfoldi, T. T. (1979). LANDSAT test of diffuse reflectance models for aquatic suspended solids measurement. Remote Sensing Environment, 8(2), 169-183. doi: https://doi.org/10.1016/00344257(79)90015-4

Murali, R. M., \& Kumar, P. D. (2015). Implications of sea level rise scenarios on land use/land cover classes of the coastal zones of Cochin, India. Journal of Environmental Management, 148, 124-133. doi: https:// doi.org/10.1016/j.jenvman.2014.06.010

Nguyen, H. H., Pullar, D., Duke, N., McAlpine, C., Nguyen, H. T., \& Johansen, K. (2010, November 1-5). Historic shoreline changes: An indicator of coastal vulnerability for human landuse and development in Kien Giang, Vietnam. In 31st Asian Conference on Remote Sensing (pp. 1835-1843). Hanoi, Vietnam.

Oumer, H. A. (2009). Land use and land cover change, drivers and its impact: A comparative study from Kuhar Michael and LencheDima of Blue Nile and Awash Basins of Ethiopia (Unpublished thesis). Cornell University, NY, USA.

Pal, B., Samanta, S., \& Pal, D. K. (2012). Morphometric and hydrological analysis and mapping for Watut watershed using Remote Sensing and GIS techniques. International Journal of Advances in Engineering and Technology, 2(1), 357-368.

Pandian, P. K., Ramesh, S., Murthy, M. V. R., Ramachandran, S., \& Thayumanavan, S. (2004). Shoreline changes and near shore processes along Ennore coast, east coast of South India. Journal of Coastal Research, 20(203), 828-845. doi: https://doi.org/10.2112/1551-5036(2004)20[828:SCANSP]2.0.CO;2 
River Research Institute. (2009). Report on the beach profile survey at Digha form West Bengal-Orissa Border to Mandermoni. Report [Hard Copy].

Rossiter, D. G. (2014). Statistical methods for accuracy assessment of classified thematic maps. Technical Note. International Institute for Geo-information Science and Earth Observation (ITC).

Saha, A. K., Arora, M. K., Csaplovics, N. E., \& Gupta, R. P. (2005). Land covers classification using IRS LISS III Image and DEM in a Rugged Terrain: A case study in Himalayas. Geocarto International, 20(2), 33-40. doi: https://doi.org/10.1080/10106040508542343

Samanta, S., \& Paul, S. (2016). Geospatial analysis of shoreline and land use/land covers changes through remote sensing and GIS techniques. Modeling Earth Systems and Environment, 2(3), 1-8. doi: https:// doi.org/10.1007/s40808-016-0180-0

SCGE. (2011). Supervised/unsupervised land use land cover classification using ERDAS imagine. Summer course computational geoecology. Retrieved May 30, 2015, from http://horizon.science.uva

Scott, A. J., \& Symons, M. J. (1971). Clustering methods based on likelihood ratio criteria. Biometrics, 27(2), 387-397.

Selvan, S. C., Kankara, R. S., \& Rajan, B. (2014). Assessment of shoreline changes along Karnataka coast, India using GIS and Remote sensing techniques. Indian Journal of Marine Sciences, 43(7), 1286-1291

Story, M., \& Congalton, R. (1986). Accuracy assessment: A user's perspective. Photogrammetric Engineering and Remote Sensing, 52(3), 397-399.

Thieler, E. R., Himmelstoss, E. A., Zichichi, J. L., \& Ayhan, E. (2009). Digital shoreline analysis system (DSAS) version 4.3. An Arc GIS extension for calculating shoreline change: U.S. Geological Survey Open-File Report 2008-1278. Retrieved November 5, 2018, from http://pubs.usgs.gov/of/2008/1278.

Trinh, L. H., Le, T. G., Kieu, V. H., Tran, T. M. L., \& Nguyen, T. T. N. (2020). Application of remote sensing technique for shoreline change detection in Ninh Binh and Nam Dinh provinces (Vietnam) during the period 1988 to 2018 based on water indices. Russian Journal of Earth Sciences, 20(2), 1-36. doi: $10.2205 / 2020$ ES000686.

Umitsu, M., \& Sen, B. (1987). Late quaternary sedimentary environment and landform evolution in the Bengal low land. Geographical Review of Japan, Series B., 60(2), 164-178. doi: https://doi.org/10.4157/ grj1984b.60.164

Van, T. T., \& Binh, T. T. (2008, December 4-6). Shoreline change detection to serve sustainable management of coastal zone in $\mathrm{Cu}$ Long Estuary. In Proceedings of the International Symposium on Geoinformatics for Spatial Infrastructure Development in Earth and Allied Sciences (pp. 1-6). Hanoi, Vietnam.

Zhang, S., Zhang, S., \& Zhang, J. (2000). A study on wetland classification model of remote sensing in the Sangjiang plain. Chinese Geographical Science, 10(1), 68-73. doi: https://doi.org/10.1007/s11769-0000038-1 